\title{
National Association of African American Studies and Affiliates 2006 National Conference
}

The National Association of African American Studies and Affiliates [National Association of African American Studies, National Association of Hispanic and Latino Studies, National Association of Native American Studies and Affiliates, International Association of Asian Studies] held its annual conference in Baton Rouge, Louisiana, on 13-18 February 2006. The conference served as host to over 580 college and university professors, as well as members of professional organizations, from across the United States and several foreign countries. In addition to the speakers who addressed issues related to the African-American, Hispanic/Latino, Asian and Native American experience, there were more than 1,200 other attendees.

A sampling of institutions represented included the University of Tennessee, six institutions from the California State system, Hampton University, Yale University, Quinnipiac University, Howard University, George Mason University, Wesleyan University, University of Kansas, and Purdue University. Additional participants and attendees came from the United Arab Emirates University, the Sequoyah Research Center, the Center for the Christian-Muslim Engagement for Peace and Justice, Cubanet News, Stewart Associates, Erudite RPC Firm, the Economic Policy Institute, and Imani Publications.

The 2006 conference also involved the Islamic and Middle Eastern Studies Association (IMESA). The participation from IMESA marks the first time this organization has held its meeting in conjunction with another organization. There were several outstanding papers presented by IMESA participants. Dr. Pisamai Vogulaar (The Center of Christian-Muslim Engagement for Peace and Justice) presented a paper entitled "Living as Muslim Minorities: A Case Study of Thai Sunni Muslims in Bangkok and Arab Sunni Muslims in Chicago." The focus of this paper was of interest to many of the conference attendees. Other outstanding presentations included "Fethullah Gullen and Islam in the Contemporary World" by Dr. Yetkin Yildirin (The Institute of Interfaith Dialog), "That Which May Not Be Spoken: Homoerotic Desire in the Writings of Ismat Chugtai and Alifa Rifaat" by Dr. Indrani Mitra (St. Mary's University), and "Seek What Brings Benefit: A Discussion of Contemporary Issues Involving Maslaha and a Few Theological Premises in Its Favor" by Mary C. Moorman (Yale University). 
The national organization and the Islamic and Middle Eastern Studies Association will join forces together in 2007 . The next conference will be held February 12-17, 2007 in Baton Rouge.

Conference attendees also attended a number of informational sessions that involved international travel. Many attendees registered to participate in the Academic Scholars Program to China and Taiwan. These academic scholars will travel to Beijing, May 21 - June 8 to lecture in a field of her/his expertise. There was also expressed interest in participating in the July SinoAmerican Research Forum which will be hosted by Guangxi Normal University in Guilin. Information in regard to the organization's new program to have 100 or more conference attendees and/or members attend the 2008 Olympics in Beijing was discussed. Again, there was much buzz about this opportunity.

Several persons were appointed to the national board. These individuals were selected based on their administrative leadership ability, academic scholarship and service to the minority community. New board members appointed for various terms include: Zafar Bokhari (Chicago State University), Ada Puryear Burnette (Valdosta State University), Shu Jen Chen (City College, SUNY), (Jaibun Earp (Florida A\&M University), Bruno Ferrer (University of Puerto Rico), Regina Jones (Syracuse University), Frank Lucido (Texas A\&M University), Shauneen Pete (University of Regina), Wendy Trott (Delaware Technical \& Community College), and Dr. Nili Luo (University of Montana-Western).

The National Association of African American Studies and Affiliates and the Islamic and Middle Eastern Studies are in the process of making arrangements for the February 2007 conference. Persons interested in acquiring information about the conference/call for papers or other national projects may visit the website at www.naaas.org.

Lemuel Berry, Jr.

Executive Director, NAAAS

Biddeford, Maine 